\title{
Mesostigmatid mite (Acari: Mesostigmata) diversity and abundance in two sites in Pedregal de San Ángel Ecological Reserve, Distrito Federal, México*
}

\author{
DANIELA PÉREZ-VELÁZQUEZ ${ }^{1,4}$, GABRIELA CASTAÑO-MENESES ${ }^{1,2}, \quad$ ALICIA \\ CALLEJAS-CHAVERO ${ }^{3}$ \& JOSÉ G. PALACIOS-VARGAS \\ 'Ecología y Sistemática de Microartrópodos, Departamento de Ecología y Recursos Naturales, Facultad de Ciencias, \\ Universidad Nacional Autónoma de México, Coyoacán 04510, México, D.F.; \\ ${ }^{2}$ Unidad Multidisciplinaria de Docencia e Investigación, Facultad de Ciencias, Universidad Nacional Autónoma de \\ México, Campus Juriquilla, Boulevard Juriquilla 3001, C.P. 76230, Querétaro, México; \\ ${ }^{3}$ Laboratorio de Ecología Vegetal, Departamento de Botánica, Escuela Nacional de Ciencias Biológicas, Instituto \\ Politécnico Nacional, Prolongación de Carpio y Plan de Ayala, Casco de Santo Tomás, Miguel Hidalgo 11340, \\ México, D.F.; \\ ${ }^{4}$ Corresponding author: E-mail: siankaan_namib@hotmail.com
}

* In: Moraes, G.J. de \& Proctor, H. (eds) Acarology XIII: Proceedings of the International Congress. Zoosymposia, 6, 1-304.

\begin{abstract}
The Pedregal de San Ángel Ecological Reserve (REPSA) is located in the central campus of the Universidad Nacional Autónoma de México (UNAM), in México City. Diversity and abundance of edaphic mites of the order Mesostigmata were estimated in two sites of REPSA. One site had scanty vegetation, due to human alterations, and was designated as "open site" (O), whereas the other had less altered, denser vegetation, being designated as "closed site" (C). Samples of soil and litter collected during the rainy and dry seasons of 2008 were processed for the extraction of mites of that group, which were then mounted and quantified by morphospecies. Mite abundance was much higher in site $\mathrm{O}$, but the number of morphospecies was about the same in both sites. The same mite families were found in both sites. For each season and for both seasons considered together, Shannon diversity and Pielou's evenness indexes were significantly higher in site C. Sörensen similarity coefficient between sites was high in both seasons, but higher in the dry season; considering both seasons together, similarity coefficient between sites was $94 \%$. This indicates that anthropogenic alteration of the vegetation at REPSA, reducing the height of the vegetation and turning it less dense, was not sufficient to cause major alterations in Mesostigmata species composition.
\end{abstract}

Key words: Abundance, diversity, edaphic, mesostigmatid mites, phenology.

\section{Introduction}

The soil is a very complex ecosystem where physical, chemical and biological processes are commonly influenced by the fauna (Jacot, 1940). For different reasons, arthropods are very important components of soil fauna. For example, they can increase soil fertility, due to their role in the fragmentation of organic matter (Bedano et al., 2005) and humus production. The best represented arthropods in the soil are mites (Acari) and springtails (Collembola). Mites constitute a very diverse group in terms of species, ecological niche they occupy and behavior (Prieto et al., 2005). The Mesostigmata constitute a mite order with high ecological diversity. They are very frequently found in the soil, being often only outnumbered by the Oribatida (Moreno-Moreno \& MayagoitiaPenagos, 2008).

Most Mesostigmata are free living predators, but many are internal or external parasites of mammals, birds, reptilians and some invertebrates, while others feed on fungi, pollen or nectar (Iraola, 1998, 2001; Lindquist et al., 2009a). Edaphic Mesostigmata feed mainly on other mites, springtails, nematodes and other invertebrates. They are medium to large mites, varying in length between 0.2 to $2 \mathrm{~mm}$. 
Due to their wide global distribution, relatively high abundance and predatory feeding habits, these mites are often at the top of the food chains in the soil, and have been considered as good indicators of environmental conditions, because many species are sensitive to natural and anthropogenic alterations. Ruf (1998) proposed the use of edaphic Mesostigmata as bioindicators (Coja \& Brucker, 2006).

The Pedregal de San Ángel Ecological Reserve (from now on referred as REPSA, according to the Spanish abbreviation) was designated a national reserve in 1983, to conserve its endemic vegetation and its extraordinary biodiversity. REPSA comprises about 232.3 ha, where a high diversity of plants and animals is found, with many endemic species (Valiente-Baunet \& Luna, 1990). Previous studies (Rueda-Salazar \& Cano, 2009; Palacios-Vargas et al., 2009) have reported only two families of mesostigmatids from the REPSA, Spinturnicidae and Podocinidae. In the present work, we estimated the diversity of mesostigmatid mites in two sites with different degrees of vegetation cover in this area, during the dry and the rainy seasons over one year.

\section{Materials and Methods}

\section{Study area}

The Pedregal de San Ángel originated about $1670 \pm 35$ years ago, as a result of the eruption of the Xitle volcano. The lava flow is located on the Ajusco slopes, occupying a surface of approximately $70 \mathrm{~km}^{2}$ (Siebe, 2009). REPSA is located in southeastern México City $\left(19^{\circ} 14^{\prime}-19^{\circ} 25^{\prime} \mathrm{N}\right.$; $\left.99^{\circ} 08^{\prime}-99^{\circ} 15^{\prime} \mathrm{W}\right)$, in the central campus of the Universidad Nacional Autónoma de México (UNAM).

REPSA soils are mainly of aeolic and organic origin. The organic matter accumulation occurs in cracks, fissures and depressions of the surface; its thickness is only a few centimeters, which makes it difficult to distinguish typical soil horizons. The soils are sandy, muddy and moderately acid, with high organic matter, potassium and calcium contents, but with low concentrations of nitrogen and phosphate (Rzedowski, 1994). The annual average temperature is around $14.0-15.5^{\circ} \mathrm{C}$, with extreme variations from 6 to $34.6^{\circ} \mathrm{C}$; annual precipitation varies between 700 and $950 \mathrm{~mm}$ (Valiente-Baunet \& Luna, 1990). According to Köppen's classification, the climate of this area is sub-humid tempered with summer rains (Soberón et al., 1994).

\section{Sampling}

In the external botanic garden of the Universidad Nacional Autónoma de México, located in the REPSA area, two sites were selected for the study, differing in their degrees of vegetation density. One was designated as "open" $(\mathrm{O})$, for having scanty vegetation due to human alteration; the other was designated as "closed" (C), for being less altered, having denser vegetation. The composition of the vegetation in both sites are similar (Castillo-Agüero et al., 2004), but the abundance of the shrub Pittocaulon (Senecio) praecox (Cav.) H. Rob. et Brettell is higher in the C site (Callejas-Chavero et al., unpublish data). In each site, three shrubs of that species were tagged at random as landmarks for successive samplings; shrubs were at least $1.5 \mathrm{~m}$ in height. A soil sample $\left(95 \mathrm{~cm}^{2}\right.$ x $5 \mathrm{~cm}$ deep) was taken monthly about $10 \mathrm{~cm}$ from the trunk of each shrub and from each cardinal quadrant, during the dry (April and June) and the rainy (July, September and October) seasons of 2008. Thus, a total of 120 samples were considered in the study. Samples were taken to the laboratory in plastic boxes, where the fauna was extracted using Berlese-Tullgren funnels during six days, three at room temperature and three at a higher temperature, obtained with a 25 watt lamp maintained about $25 \mathrm{~cm}$ of the surface of the sample in each funnel. Mites extracted were examined under a stereomicroscope and mesostigmatid mites were isolated and quantified to morphospecies. Three mites of each morphospecies were then mounted in Hoyer's medium, using 
the technique suggested by Palacios-Vargas \& Mejía-Recamier (2007), to confirm that they belonged to the same morphospecies and that they were different from other morphospecies.

\section{Statistical analysis}

Shannon diversity (H') and Pielou's evenness (J') indexes were calculated for different combinations of seasons and sites. Differences between diversity indexes were analyzed by modified t-tests (Zar, 1984). The analyses were performed by Statecol Ver. 1.12.03 program. Comparison of the community compositions between seasons and sites was performed by Sörensen similarity coefficient.

\section{Results}

A total of 8,156 mesostigamatids were collected, 2,743 from site $\mathrm{C}$ and 5,413 from site $\mathrm{O}$ (Table 1). In total, they represented 19 morphospecies of eight families. The most abundant families were Ascidae with 3,479 specimens $(\mathrm{C}=800, \mathrm{O}=2,679)$ and Rhodacaridae with $1,687(\mathrm{C}=680, \mathrm{O}=$ $1,007)$, while the least abundant family was Ologamasidae with $29(\mathrm{C}=15, \mathrm{O}=14$; Fig. 1$)$.

TABLE 1. Number of morphospecies (MS) and abundance (Abund.) of each mesostigamatid family represented in the Open and Closed sites at Pedregal de San Ángel Ecological Reserve, México City, México, in the rainy and dry seasons of 2008 .

\begin{tabular}{|c|c|c|c|c|c|c|c|c|}
\hline \multirow[b]{3}{*}{ Family } & \multicolumn{4}{|c|}{ Open } & \multicolumn{4}{|c|}{ Closed } \\
\hline & \multicolumn{2}{|c|}{ Rainy } & \multicolumn{2}{|c|}{ Dry } & \multicolumn{2}{|c|}{ Rainy } & \multicolumn{2}{|c|}{ Dry } \\
\hline & MS & Abund. & MS & Abund. & MS & Abund. & MS & Abund. \\
\hline Ascidae & 3 & 1861 & 3 & 818 & 3 & 582 & 3 & 218 \\
\hline Blattisociidae & 1 & 19 & 1 & 16 & 1 & 19 & 1 & 10 \\
\hline Laelapidae & 3 & 394 & 3 & 208 & 4 & 370 & 2 & 136 \\
\hline Macrochelidae & 1 & 167 & 1 & 32 & 1 & 235 & 1 & 39 \\
\hline Ologamasidae & 1 & 1 & 1 & 13 & 1 & 14 & 1 & 1 \\
\hline Phytoseiidae & 3 & 98 & 2 & 19 & 2 & 170 & 2 & 45 \\
\hline Rhodacaridae & 2 & 777 & 2 & 230 & 2 & 492 & 2 & 188 \\
\hline Uropodidae & 4 & 663 & 3 & 97 & 4 & 194 & 1 & 30 \\
\hline Totals & 18 & 3,980 & 16 & 1,433 & 18 & 2,076 & 13 & 667 \\
\hline
\end{tabular}

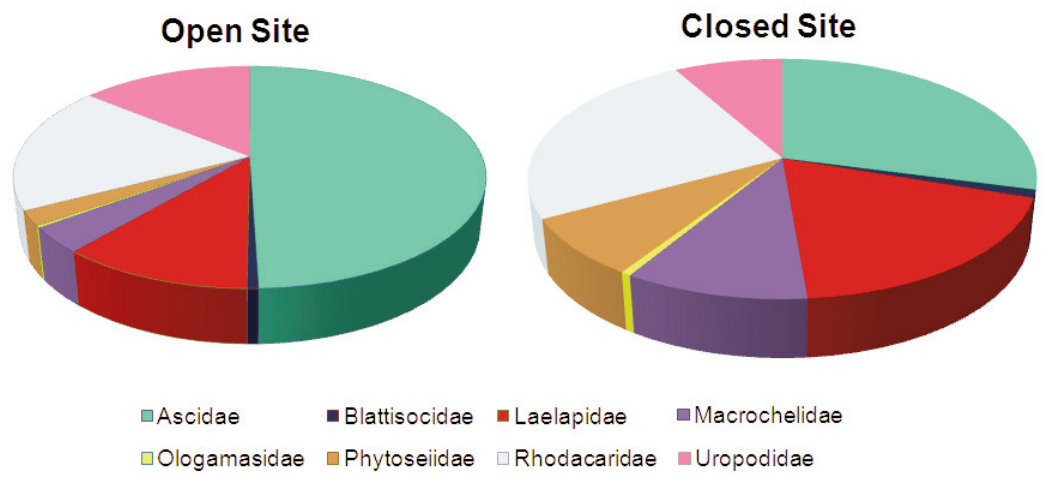

FIGURE 1. Family composition of mesostigmatid mites in two sites in the Pedregal de San Ángel Ecological Reserve, México City, México. 2008. 
The same families were present in both sites. Total numbers of morphospecies were: Uropodidae, four; Ascidae, Laelapidae and Phytoseiidae, three each; Rhodacaridae, two; Blattisociidae, Macrochelidae and Ologamasidae, one each. The total numbers of morphospecies were 19 in site $\mathrm{O}$ and 18 in site $\mathrm{C}$, with 17 (97\%) of the morphospecies shared in both sites and seasons .

For each season and for both seasons combined, Shannon diversity indexes $\left(\mathrm{H}^{\prime}\right)$ were significantly higher in site $\mathrm{C}$ (Table 2 ). Calculated Pielou's evenness indexes ( $\left.\mathrm{J}^{\prime}\right)$ were also higher in site $\mathrm{C}$ for comparisons within each season and for both seasons considered together. Calculated Sörensen similarity coefficient (SC) between sites was high in each season (but higher in the dry season), and consequently also in both seasons considered together.

\section{Discussion}

In both seasons, the highest abundance of mesostigmatid mites occurred in the site with higher anthropogenic influence, that is, site $\mathrm{O}$, in which the vegetation was less dense. The opposite was observed in relation to the indices of diversity and evenness. Thus, disturbances of site $\mathrm{O}$ seemed to favor the increase in the population of mesostigmatid mites, but the increase was not even among species, some increasing much more than others. The diversity indices as well as similarity coefficients showed a clear difference between both rainy and dry seasons, suggesting that environmental conditions in the soil, such as humidity, could be responsible for this difference (Moraza, 2007; Fuentes et al., 2008).

Regardless of the differences in mite abundance, the sites were very similar, as indicated by the high values of Sörensen similarity coefficients. This suggests that anthropogenic influence was not sufficient to cause major differences in Mesostigmata species composition between the two studied sites.

The types of data recorded in this work were not sufficient to explain the reason why the abundance of species of some families was higher in the site $\mathrm{O}$, whereas species in other families had the opposite trend. This difference could be related to the different feeding habits of mites of each family. For example, while Phytoseiidae mites, much more abundant in the $\mathrm{C}$ site, are mostly predators (although some plant inhabiting phytoseiid groups are known to feed on pollent), Ascidae and Uropodidae mites, much more abundant in the $\mathrm{O}$ site, seem to have much more general feeding habits (Gerson et al., 2003; Lindquist et al., 2009b). Care should be taken, however, because feeding habits vary within each of those groups. Thus, a more precise determination of the reason for the observed differences in variation between mite families depends upon the specific determination of the species collected.

\section{Acknowledgments}

This study was supported by PAPIIT-IN208508 project, founded by Dirección General de Asuntos del Personal Académico, UNAM. M. Magdalena Vázquez (Universidad de Quintana Roo) identified the uropodid species. Miguel Blanco (†), Leopoldo Cutz, Arturo García and Sandra Gómez assisted in the field work, and Ricardo Iglesias (Fac. Ciencias, UNAM) reviewed the final manuscript. Kenneth A. Christiansen (Grinnell College, Iowa, USA), and Gilberto J. de Moraes corrected the manuscript. 


\section{References}

Bedano, J.C., Cantú, M.P. \& Doucet, M.E. (2005) Abundance of soil mites (Arachnida: Acari) in natural soil of central Argentina. Zoological Studies, 44, 505-512.

Castillo-Agüero, S., Montes-Cartas, G., Romero-Romero, M.-A., Martínez-Orea, Y., Guadarrama-Chávez, P., Sánchez-Guillén, I. \& Núñez-Castillo, O. (2004) Dinámica y conservación de la flora del matorral xerófilo de la Reserva Ecológica del Pedregal de San Ángel (D.F., México). Boletín de la Sociedad Botánica de México, 74, 51-75.

C̆oja, T. \& Brucker, A. (2006) The maturity index applied to soil gamasine mites from five natural forest in Austria. Applied Soil Ecology, 34, 1-9.

Fuentes, L., Vásquez, C., Palma, W. \& Bari, C. (2008) Ácaros Prostigmata y Mesostigmata asociados a la hojarasca del bosque de galería del parque universitario de la UCLA, estado Lara, Venezuela. Neotropical Entomology, 37, 591-596.

Gerson, U., Smiley, R.L. \& Ochoa, R. (2003) Mites (Acari) for pest control. Blackwell Science Ltd, Oxford.

Iraola, V. (1998) Introducción a los ácaros (I): Descripción general y principales grupos. Boletín de la Sociedad Entomológica Aragonesa, 23, 13-19.

Iraola, V. (2001) Introducción a los ácaros (II): hábitats e importancia para el hombre. Boletín de la Sociedad Entomológica Aragonesa, 28, 141-146.

Jacot, A.-P. (1940) The fauna of the soil. The Quarterly Review of Biology, 15, 28-58.

Lindquist, E.E., Krantz, G.W. \& Walter, D.E. (2009a) Classification. In: Krantz, G.W. \& Walter, D.E. (eds) A manual of acarology, $3^{\text {rd }}$ edition. Texas Tech University Press, Lubbock, pp. 97-103.

Lindquist, E.E., Krantz, G.W. \& Walter, D.E. (2009b) Order Mesostigmata. In: Krantz, G.W. \& Walter, D.E. (eds) A manual of acarology, 3rd edition. Texas Tech University Press, Lubbock, pp. 124-232.

Moraza, M.L. (2007) Composición, estructura y diversidad de la comunidad de ácaros mesostigmata de un hayedo natural (Fagus sylvatica) del sur de Europa. Grallsia, 63, 35-42.

Moreno-Moreno, J.-A. \& Mayagoitia-Penagos, M. (2008) Estudio de ácaros mesostigmados del suelo y su estado actual en México. In: Estrada-Venegas, E.G (ed) Fauna del suelo I micro, meso y macrofauna. Colegio de Postgraduados, Estado de México, pp. 33-49.

Palacios-Vargas, J.-G. \& Mejía-Recamier, B.-E. (2007) Técnicas de colecta, montaje y preservación de microartrópodos edáficos. Universidad Nacional Autónoma de México, Las prensas de Ciencias, México, D.F.

Palacios-Vargas, J.-G., Mejía-Recamier, B.-E. \& Cutz-Pool, L.-Q. (2009) Microartropodos edáficos. In: Lot, A. \& Cano-Santana, Z (eds) Biodiversidad del ecosistema del Pedregal de San Ángel. Universidad Nacional Autónoma de México. México, D.F., pp, 203-211.

Prieto, D., González, V. \& Tcherva, T. (2005) Microartrópodos asociados a la hojarasca de un bosque semideciduo de Bacunayagua, Matanzas, Cuba. Revista Biología, 19, 57-64.

Rueda-Salazar, A.-M. \& Cano-Santana, Z. (2009) Artropodofauna. In: Lot, A. \& Cano-Santana, Z. (eds) Biodiversidad del ecosistema del Pedregal de San Ángel. Universidad Nacional Autónoma de México. México, D.F., pp. 171-201.

Ruf, A. (1998) A maturity index for predatory soil mites (Mesostigmata: Gamasina) as an indicator of environmental impacts of pollution on forest soils. Applied Soil Ecology, 9, 447-452.

Rzedowski, J. (1994) Vegetación del Pedregal de San Ángel. Reserva ecológica "El Pedregal de San Ángel". In: Rojo, A. (ed) Ecología e historia natural y manejo. Universidad Nacional Autónoma de México, México, D.F., pp. 9-65.

Siebe, C. (2009) La erupción del volcán Xitle y las lavas del Pedregal hace 1670 +/- 35 años AP y sus implicaciones. In: Lot, A. \& Cano-Santana, Z (eds) Biodiversidad del ecosistema del Pedregal de San Ángel. Universidad Nacional Autónoma de México, México, D.F., pp. 43-49.

Soberón, J., Rosas, M. \& Jiménez, G. (1994) Ecología hipotética de la reserva del Pedregal de San Ángel. In: Rojo, A (ed.) Reserva ecológica "El Pedregal de San Ángel". Ecología e historia natural y manejo. Universidad Nacional Autónoma de México, México, D.F., pp. 129-148.

Valiente-Baunet, A. \& Luna, E. (1990) Una lista florística actualizada para la Reserva del Pedregal de San Ángel, México, D.F. Acta Botánica Mexicana, 9, 13-30.

Zar, J.H. (1984) Biostatistical analysis, $2^{\text {nd }}$ edition. Prentice Hall, New Jersey. 